\title{
The Innovation of the Autonomous System for Indoor Illuminance Measurement
}

\begin{abstract}
The goal of this report is to show the results we achieved in the field of autonomous indoor illuminance measurement. At the beginning of the paper the state of the art measurement methodology is shown. It is followed by the description of the robotic unit we designed for the purpose of automation of the measurement process. Moreover, the algorithm for measurement process is described in detail. The rest of the paper deals with possible improvements of the robotic platform mainly by adding new sensors and by adding the illuminance vector measurement unit.
\end{abstract}

Keywords: robot, measurement, illuminance, sensor

\section{Introduction}

The lightning measurement in control points is the most used principle of verifying parameters of the lightning system in an interior. The lightning measurement is timeconsuming because of various technological standards requirements for the control points net. The main goal of this thesis is to make this way more efficient thanks to automation of a measuring unit.

In the previous period I designed, made, revived and tested a robotic unit which, using luxmetr, was acquiring and processing a measured quantity. My intention was to choose more suitable sensor which would be used for better control points mapping and the robot localization in an empty pre-defined room.

\section{Present methodology of measurement}

Lightning in an interior is measured in control points which need to be defined precisely. The Czech technological norm CSN 360011 - 1 [1] defines the procedure of measuring and control points setting is following.

For the assessment of lightning distribution indoor, outer lines are placed $1 \mathrm{~m}$ from inner wall surface on the horizontal level reference. Other control points are placed in regular distance with density with the regard to the indoor height and other factors (placing of lightning vents, lights, etc.). The space progress, changes in the lightning and if possible even places with the highest and lowest light need to be noticed. In smaller interior places the control points distance is usually 0,5 to $2 \mathrm{~m}$, in larger indoor places with high height the distance can be up to $6 \mathrm{~m}$ (figure 1). The number of points and their pitches are chosen according to the placement of lightning on the level reference.

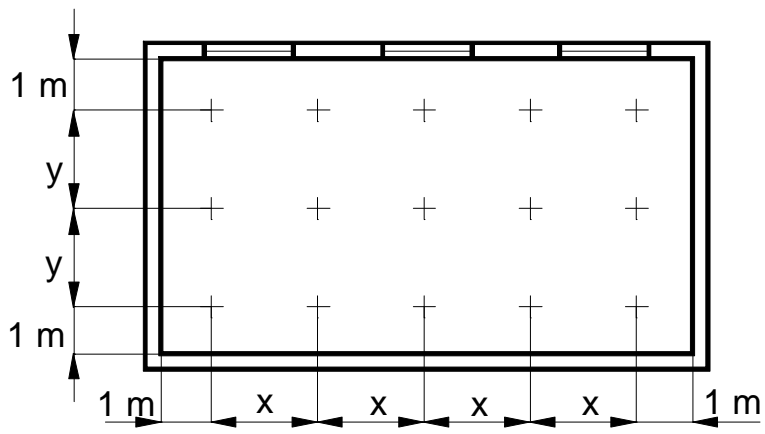

Fig. 1. Placement of control points indoor

The lightning measurement is done manually in practice. It means that firstly the control points are set and then, using luxmetr in control points, the measuring is done. Because it is about large places according to the technological norm, such as public buildings (schools, libraries), the manual measurement is time-consuming.

\section{Autonomous system and lightning process description}

My previous work was the development and testing of a robotic unit (figure 2) which is able to measure lightning in empty pre-defined room ground plans. The equipment was oriented in space using odometry and touch sensors (micro switches). The calculation of odometry was performed by a board computer which proceeded data of encoders which were situated in motors.

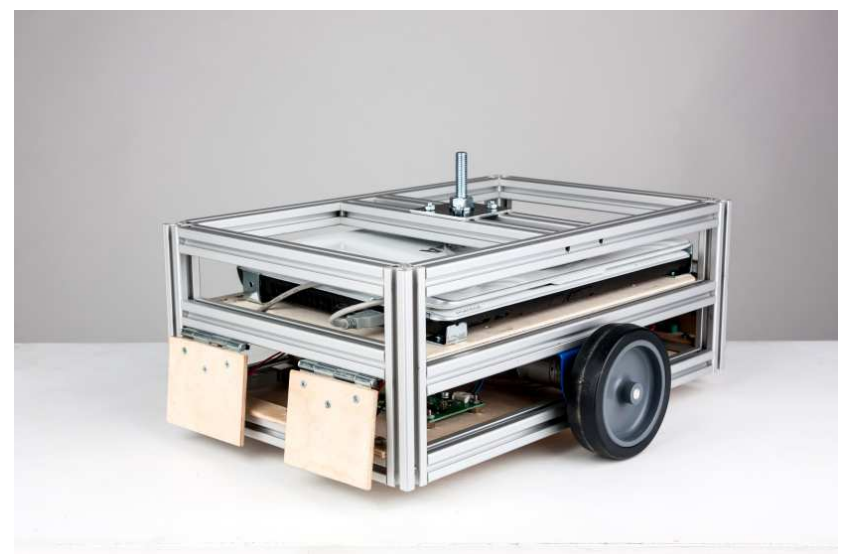

Fig. 2: Robotic unit

The entire process of lightning measurement indoor was divided into two follow-up parts. The first part included an identification of room dimensions using a linear rolling of unit and a follow-up wall detection using tactile sensors. After defining the size, the control points and pitches were set (figure 3). The lightning measurement was carried out using luxmetr attached to the unit on particular places.

The second part of the programmed algorisms was to drive onto specific points and carry out measurement and a follow-up location record and measured values into a chart which was shown to the service at the end of the measuring.

During the testing a mistake in the place determination has been discovered. This mistake could not be removed even though the calculating of odometry and different types of regulators were improved. Because of that a solution was made at the end of the work. The solution was a change of the sensor for defining position 
$5,6 \mathrm{~m}$

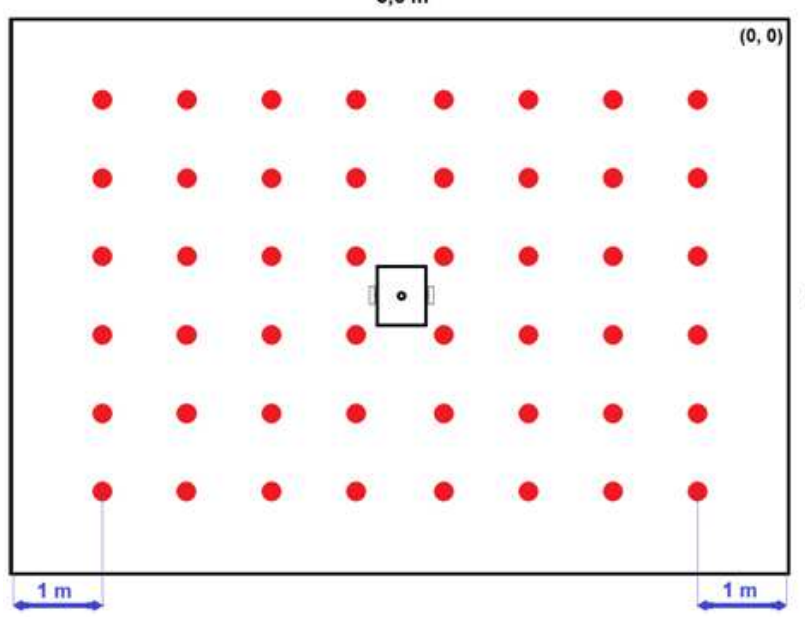

Fig. 3: Control points placing indoor

\section{Suitable sensor choosing}

Various sensors can be used for stating the distance from walls, or more precisely for the robot's orientation in any formed space. Some sensor, e.g. ultrasound or infrared, are ideal for the wall detection but they have unsatisfactory coverage. If we used the sensors in a room $15 \times 20 \mathrm{~m}$, they would be ineffective. That is the reason why below mentioned machines have been chosen because they are mostly used in identifying location in large areas. Characteristics of chosen sensors are stated in Tab. no 1.

1. GPS

GPS is widely used device for location identification. The system works on the principle of receiving signal from some satellites which orbit around the Earth.

For example, device spectrum telemetry - GPS sensor is sold for $2.899 \mathrm{CZK}$. The sizes are $14 \times 20 \times 36 \mathrm{~mm}$ and the weight is $10.8 \mathrm{~g}$.

\section{Magnetic compass}

Magnetic compass is used in robotic applications for location identification in space. An example is Petr Pilch's bachelor thesis which deals with an analysis of compass usage for mobile robot navigation indoor [2]. The machine works on the principle of the Earth magnetic field.

GY-273 HMC588L is an example of a magneticelectronic compass and is sold for 55 CZK. The sizes are $19 \times 14 \times 2 \mathrm{~mm}$ and the weight is $2 \mathrm{~g}$.

3. IMU

This device uses gyroscopes and accelerometers for stating an angular deviation from the reference coordinate system.

There are several types, for example GY-85 9DOF IMU which costs $210 \mathrm{CZK}$. The sizes are $22 \times 16 \times 3 \mathrm{~mm}$ and the weight is $31 \mathrm{~g}$.

\section{Stereo camera}

Two cameras are used with an exact calibration for the scene reconstruction. Using detection of the reference point which will be situated on the unit, the robot could be guided. The assumption for this are two cameras situated in a proper place of a room where they should cover the most space. The unit could be located everywhere in the room. This way is not suitable because it is not possible to state the distance from the walls.

Another possibility is to place cameras on the unit so the board computer detects a wall and it states, using calculations, the distance from it.

\section{Encoders}

On the basis of pulsations of indoor probes, which are usually situated on the motor shaft, driven distance and turning are calculated using integration.
This type of sensor was used in the previous version of location identification of the unit with error rate and unsatisfactory accuracy. [3]

\section{Optical sensors}

The sensor is based on the optical mouse principle, and uses the method of comparing two sequent pictures. The sensor was made and tested in Lenka Mudrova's bachelor thesis "Systems of localizations of mobile robot" [4].

\section{Beacon localization}

This method uses e.g. ultrasound beacons placed properly in the room (corners). The unit location can be defined on the basis of trilateration. This localization is described in details and tested in bachelor thesis. [4].

\section{Laser rangefinder}

This device uses laser rays to define the distance from the barrier (wall), these rays are transmitted to the degree scale and it gains information about the surrounding space.

TIM551-2050001 from the SICK Company is an example of laser rangefinder. It costs about 60,000 CZK, sizes are $60 \times 60 \times 86 \mathrm{~mm}$ and it weighs $250 \mathrm{~g}$.

Table 1: Sensor characteristics

\begin{tabular}{|c|c|c|}
\hline Unit & Advantages & disadvantages \\
\hline GPS & $\begin{array}{c}\text { Price, sizes, } \\
\text { implementation and } \\
\text { weight }\end{array}$ & $\begin{array}{l}\text { Working only outdoor } \\
\text { and accuracy }\end{array}$ \\
\hline $\begin{array}{l}\text { Magnetic } \\
\text { compass }\end{array}$ & $\begin{array}{c}\text { Price, size and } \\
\text { weight }\end{array}$ & $\begin{array}{l}\text { Resistance to metal } \\
\text { items and accuracy }\end{array}$ \\
\hline IMU & $\begin{array}{c}\text { Price, size and } \\
\text { weight }\end{array}$ & Error incrimination \\
\hline Stereo camera & price & $\begin{array}{c}\text { Implementation, } \\
\text { various wall surfaces, } \\
\text { complicated } \\
\text { calibration }\end{array}$ \\
\hline encoders & $\begin{array}{c}\text { Implementation, } \\
\text { price, resistance and } \\
\text { versatility }\end{array}$ & Error incrimination \\
\hline $\begin{array}{c}\text { Beacon } \\
\text { localization }\end{array}$ & Price and accuracy & Mobility and distance \\
\hline Optical sensor & Price and accuracy & $\begin{array}{c}\text { Production, testing, } \\
\text { calibration, various } \\
\text { wall surfaces and } \\
\text { error accumulation }\end{array}$ \\
\hline $\begin{array}{c}\text { Laser } \\
\text { rangefinder }\end{array}$ & $\begin{array}{l}\text { Accuracy, size, } \\
\text { weight, } \\
\text { implementation, } \\
\text { defining the } \\
\text { distance from the } \\
\text { barrier, quick } \\
\text { assessment of } \\
\text { sizes and ground } \\
\text { plans }\end{array}$ & price \\
\hline
\end{tabular}

The choice of the sensor was done on the basis of tab. no 1 . The most suitable unit for location identification from wall indoors is the laser rangefinder which is able to find out its location using ray reflections from the barrier. It also enables future extension of a measuring task on any shapes of rooms.

\section{Improved algorithm description}

A new algorithm for the detection process of the unit in space was created on the basis of the chosen unit. The process is again divided into two parts; in the first part the size of the room is set and in the second part its measurement is carried out.

The device will be located in the middle of the room. After time which is needed for the luminous flux stabilization, the robot will start to detect parts of a wall in the room using laser rangefinder and identify the distance from them. These detected parts of the wall will be 
interspersed with a straight line and where the intersection points are about to come into being these places will be the corners of the room. The result of this is time saving because it is not needed to map the room into details.

As soon as all 4 corners of the room are calculated the control points will be set according to the sizes of the room and as well pitches between them will be set. The second phase is identical to the previous version of algorithm.

\section{Possible extension of robotic unit}

The future research will be focused on the production of the robotic unit of the second generation with a new machine for identifying a luminous vector.

The luminous vector is a vector of a luminous flux density which defines a measuring output of a luminous energy transfer wherever in the scope independently on the choice of coordinates. Its size is set by the energy which goes through it in unit of time per unit space which is perpendicular to the lightning direction. Also it is equal to the difference between normal lightings of one and as well the second side of the space located in a particular point perpendicularly to the lightning direction. The oriented direction of a lightning vector is set by the direction of the luminous energy transmission.

The lightning vector in the scope of some luminous sources is defined in every single point with the sum of partial lightning vectors which characterize the scope of single sources in a considerate point. [5]

The ideal measurement of lightning vector in a particular control point takes place in six levels at the same time. It is a problem which is difficult to put into practice.

\section{Present condition}

Nowadays 2 methods are used to do the measurement. Both methods have something in common - they need human service which sets and determines the position of measuring devices (control point).

The first principle of lightning vector measuring is done thanks to one photocell which we can rotate around its horizontal and vertical axis. The scheme is represented in the figure 4. One disadvantage of this measuring is a time lag during measuring. The manipulation of the device, setting the right position of control point during the measuring of lightning vector perpendicularly to the floor, causes a measuring mistake because of its construction device shading. The price and calibration are advantages of this device.

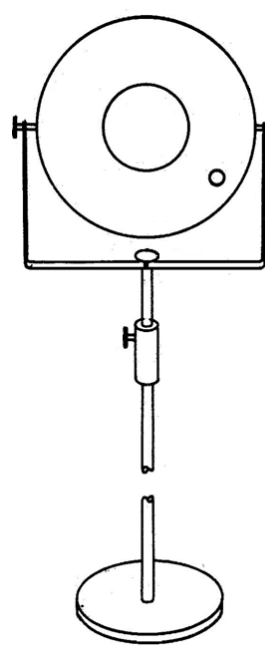

Fig. 4: The device scheme for lightning vector measuring with one photocell
The second principle of measuring is ensured with six photocells which are place in a cube. The scheme of measuring apparat is represented in the figure 5 .

The measuring of lightning vector at one moment and uncomplicated manipulation with the apparat are advantages of it. The price, service, calibration of all photocells and the size are disadvantages and it does not meet the requirements.

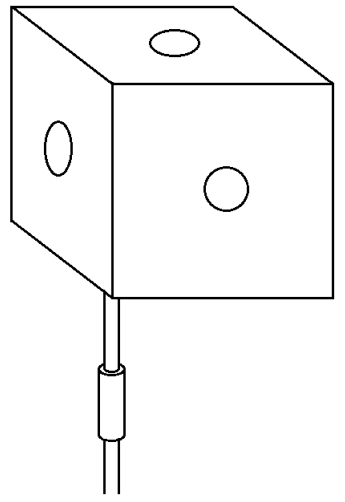

Fig. 5: Device for measuring lightning vector with six photocells

\section{New measuring apparat description}

If the measurement was automatically without human service strike, the environment of the interior would change minimally, and so the measurement in the control point could be taken in a longer time interval. When accepting this condition, a cheaper version of measuring device could be used and the handling base with a photocell would be reworked to prevent errors when setting the value during the photocell position perpendicularly to the floor.

\section{The measurement process}

As mentioned before, the lightning vector is set by the summary of partial lightning vector of particular sources. The calculating can be made easier if the luminous sources are turned on individually and the follow-up results can be summed algebraically.

The minimum time of preliminary ageing of the luminous sources has to be kept for artificial lightning measurement. It means that before the beginning of the measuring bulbs must light at least 10 hours non-stop, discharge sources (included fluorescent lamps) at least 100 hours.

The methodology itself is the same as lightning measurement. The measurement at particular places takes place during setting out the control points. The difference from lightning measurement is in gradual connection of luminous sources.

\section{Conclusion}

The aim of this article was to find an adequate sensor which would compensate the defects and using data encoder fusion the accuracy was ensured. The choice of sensor was based on the theory because of finances the measurement could not be done and testing of all the mentioned sensors as well. However, sensors mentioned in this article are often used in various combinations or individually on robots in different applications and that is the reason why their characteristics and advantages are known.

Sensors based on the principle of calculating the driven distance from a reference point carries the risk of error accumulation. Sensors using optical surface scanning or detection of the location from the picture have the main disadvantage of accuracy with various types of surface textures. I found out (information in the table 1) that for setting the distance from the wall the most suitable is a 
sensor which can discover its distance at the present point. Two sensors, which have the required characteristic, are mentioned in this article: beacon localization and laser rangefinder.

Nevertheless, the beacon localization does not have adequate reach $a$ it requires installation and proper placement of beacons in the room. The time saving would not be achieved. The laser rangefinder was the most suitable sensor.

The algorithm was improved, after choosing the right sensor. Especially the part which is used for the robot orientation in the room. This algorithm is going to be tested in near future.

The article also deals with the basis situation in lightning vector measurement and future improved apparat for its discovery. The production of new measurement device and its testing will be realized during next research.

This work was supported by the Grant Agency of the Czech Technical University in Prague, grant No. SGS15/211/OHK3/3T/13.

\section{REFERENCES}

[1] Česká technická norma ČSN 360011 - 1. Měření osvětlenosti vnitřních prostorů - Část 1: Základní ustanovení. Český normalizační institut, 2005, $13 \mathrm{~s}$.

[2] PILCH P.: Bakalářská práce: Analýza využitelnosti kompasu pro navigaci mobilního robotu $v$ indoor prostředí. 2011, 30 s.

[3] DRÁBEK, T.: Diplomová práce: Robotická jednotka pro měřeni osvětlenosti vinteriérech v rovnoměrné optimalizované síti kontrolních bodů. 2014, $54 \mathrm{~s}$.

[4] MUDROVÁ L.: Bakalářská práce: Systémy lokalizace mobilního robotu. 2010, $46 \mathrm{~s}$.

[5] Odborné časopisy - Základy světelné techniky [online]. Poslední editace 25. 11. 2014 v 15:31 [cit 25. 11. 2014]. http://www.odbornecasopisy.cz/zaklady-svetelne-techniky-338906.html

\section{Authors:}

Ing. Tomáš Drábek, České vysoké učení technické v Praze, Fakulta elektrotechniká, Technická 216 627, Praha 6, Czech Republic, e-mail: drabeto3@fel.cvut.cz

Doc. Ing. Jan Holub Ph.D. České vysoké učení technické v Praze, Fakulta elektrotechnická, Technická 216 627, Praha 6, Czech Republic, e-mail: holubjan@fel.cvut.cz 